\title{
Blindness after cosmetic blepharoplasty: case report
}

\author{
Cegueira após blefaroplastia estética: relatodecaso
}

\author{
Flávio Mac Cord Medina ${ }^{1}$ \\ Paulo de Tarso Ponte Pierre Filho ${ }^{2}$ \\ Héverton Barbosa de Freitas ${ }^{3}$ \\ Fabrício Kafury Pereira Rodrigues ${ }^{4}$ \\ Roberto Caldato ${ }^{5}$
}

\begin{tabular}{|l|}
\hline \multicolumn{1}{|c|}{ ABSTRACT } \\
\hline Blepharoplasty is one of the most commonly performed surgeries for \\
rejuvenation of the periorbital region. We present a case of unilateral \\
permanent visual loss following a bilateral lower lid cosmetic blepharoplasty \\
with fat removal. The etiology of retrobulbar hemorrhage following blepha- \\
roplasty, treatment, and recommendations to reduce the chance of this rare \\
but serious complication are discussed.
\end{tabular}

Keywords: Blindness/etiologia; Blepharoplasty/adverse effects; Retrobulbar hemorrhage/ complications; Postoperative care; Adipose tissue/surgery; Surgery, plastic/adverse effects; Case reports [publication type]

\section{INTRODUCTION}

Blindness following cosmetic blepharoplasty is a dramatic and devastating complication for both patient and surgeon. Although the exact incidence is unknow, fortunately this disastrous outcome is so rare that few blepharoplasty surgeons will ever encounter it. According to DeMere et al., in a survey of 3000 physicians in the United States performing blepharoplasties, the frequency of blindness as a complication was found to be $0.04 \%{ }^{(1)}$. In 1988, Peruzzo and Mélega report an incidence of $0.016 \%$ of visual loss following cosmetic eyelid surgery in Brazil calculated from their questionnaire covering 47,532 cases $^{(2)}$.

The exact pathophysiologic mechanism that leads to blindness is still unknown, but almost all patients blinded by blepharoplasty have been associated with orbital fat removal and deep orbital hemorrhage ${ }^{(3-4)}$. We describe a case of a unilateral visual loss after a cosmetic lower lid blepharoplasty.

\section{CASE REPORT}

A 66-year-old white female underwent a bilateral cosmetic upper lid blepharoplasty with fat excision without complication. Four months later she was scheduled to undergo cosmetic bilateral lower lid blepharoplasty, also with fat excision. Her past ocular history also revealed a bilateral cataract extraction by phacoemulsification in both eyes. Her best-corrected visual acuity was 6/9 in the right eye (RE) and 6/6 in the left eye (LE). She had mild systemic hypertension and severe pulmonary emphysema. She was taking captopril, aminophylline and prednisone. Her Goldman Risk Score was II.

On the day of the surgery, her blood pressure was 170/110 $\mathrm{mmHg}$ and she was medicated preoperatively with $25 \mathrm{mg}$ captopril. Before entering the operating room, her pressure was $130 / 80 \mathrm{mmHg}$.

The procedure was performed under local anesthesia with infiltration of $2 \%$ lidocaine with adrenaline. Fat excision was performed without difficulty. The fat presented easily and hemostasis was achieved by cauterizing the 
cut end of fat before releasing the hemostat. The orbital septum was not sutured. There was little oozing during the procedure, controlled by a bipolar cautery. She was discharged 30 minutes later with no bandage. Later that night she presented with bilateral severe orbital pain and marked swelling that were greater in the left side, requiring codeine.

On the first postoperative day, she was examinated by the Oculoplastic Service. Examination revealed an extensive bilateral lower lid edema, ecchymosis, and left subconjunctival hemorrhage (Figure 1). She was instructed to apply cold compress to the skin to reduce swelling and bruising. Two days later, she complained of sudden left eye low vision, upon awaking. Her visual acuity was 6/9 RE and no light perception LE. The left pupil was fixed and semidilated. She had no limitations on gazing and no proptosis. The intraocular pressures were $14 \mathrm{mmHg}$ RE and $22 \mathrm{mmHg}$ LE. Fundoscopic appearance was normal colored retina and the central retinal arteries were open in both eyes. The left optic disc was pale with mild swelling. The right optic disc was normal. An orbital CT performed 7 days after surgery revealed a small soft tissue density in the inferior aspect of the left orbit. There was no proptosis and the optic nerve was not displaced. The right orbit was normal. Subsequent complete hematologic evaluation failed to disclose any abnormalities of coagulation. Visual acuity remained no light perception in LE.

\section{DISCUSSION}

Visual loss following blepharoplasty is well-described in the literature, but the mechanism has not been completely understood. The most likely factor is increased orbital pressure and vascular impairment subsequent to hemorrhage or edema within the orbit induced by operative manipulation ${ }^{(3-6)}$. Total vascular insufficiency for 60-120 minutes produces permanent loss of vision ${ }^{(7)}$. Increased intraorbital pressure can produce a central retinal artery ${ }^{(8)}$ or vein ${ }^{(3)}$ occlusion with

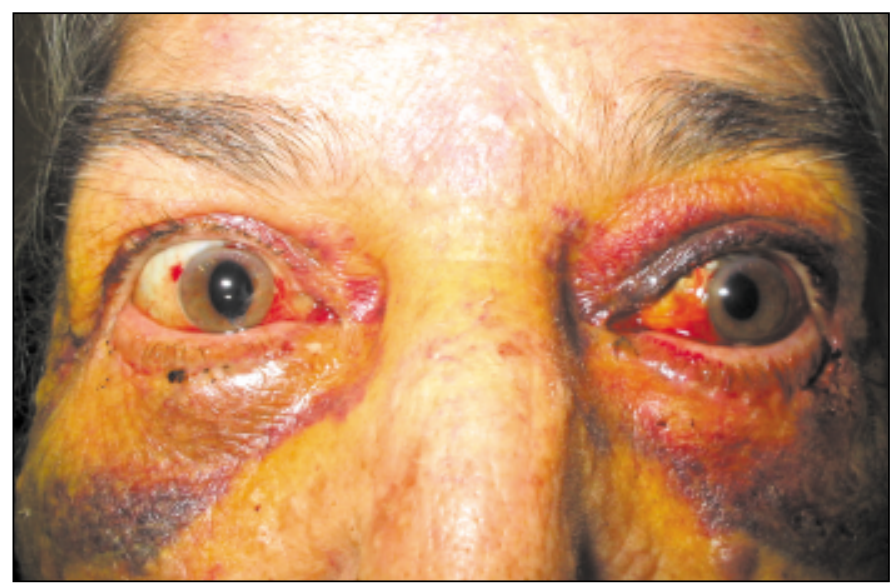

Figure 1 - Photograph taken 5 days after cosmetic lower lid blepharoplasty showing bilateral periorbital edema, ecchymosis and subconjunctival hemorrhage

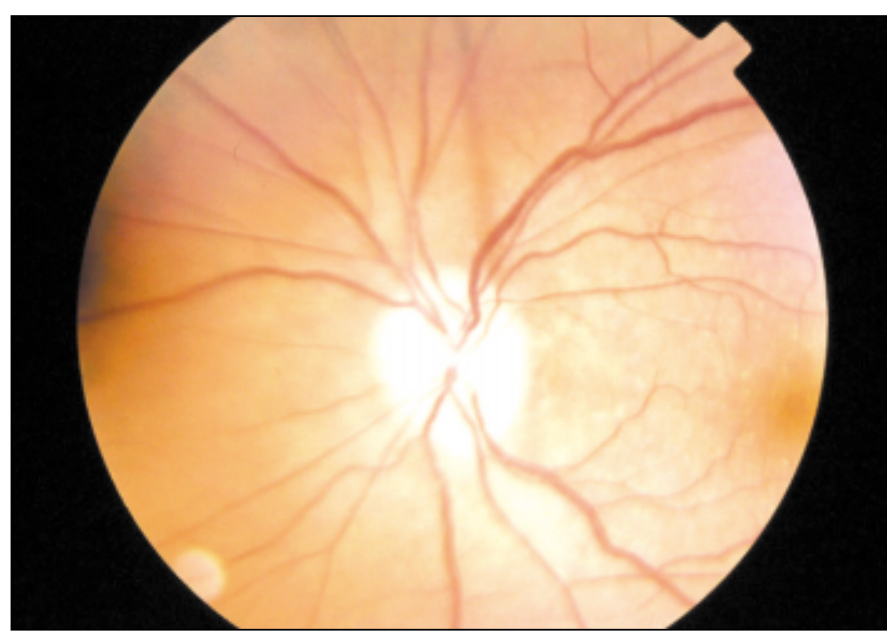

Figure 2 - Retina photograph on the $4^{\text {th }}$ day after the surgery, demonstrating a pale left optic disc with mild swelling

ischemia of the anterior optic nerve or angle-closure glaucoma in susceptible individuals ${ }^{(6)}$.

Ischemia unrelated to intraorbital bleeding is spasm within the concerned vessels and this has emerged. Theoretically it could be caused by pulling on the fat pedicles or by the use of vasopressor agents such as adrenaline in the local anesthetic infiltrates, or by the action of vasoactive agents released from extravasated blood $^{(9)}$.

Clinically the signs and symptoms of orbital hemorrhage are an acute onset of orbital pain with an increased intraorbital pressure manifested by proptosis, lid ecchymosis, increased intraocular pressure, limited extraocular muscle movement, and a dilated, unresponsive pupil. Visual acuity is usually reduced but can range from $6 / 6$ to no light perception ${ }^{(9)}$. In our case, there was marked subconjunctival hemorrhage associated with marked edema or congestion of the intraorbital fat. We suggest that orbital hemorrhage caused increased intraorbital pressure with consequent ischemia of the optic nerve resulting in visual loss of the left eye.

Orbital ultrasound or CT may not be indicated in an emergency situation, particularly if it will delay management of a tense orbit $^{(3)}$. In our case orbital CT scan demonstrated orbital hematoma, consistent with the widely accepted theory that orbital bleeding is the initiating event in postblepharoplasty visual loss.

Treatment of postblepharoplasty visual loss should be directed toward managing the probable cause of loss. Authors have recommended diverse strategies for emergency treatment of orbital hemorrhage, including ocular hypotensives $^{(1,8)}$, exploration and evacuation of the wound ${ }^{(10-11)}$, lateral canthotomy $^{(12-13)}$, orbital decompression ${ }^{(3)}$, and anterior chamber paracentesis ${ }^{(14-15)}$. Unfortunately immediate attempts to decompress the optic nerve were not made in this case.

Blindness associated with cosmetic blepharoplasty is a rare but real occurrence. To prevent this disastrous complication, more effort must be made to eliminate orbital hemorrhage. Patients should have careful preoperative examination. Visual 
acuity in each eye should be taken and recorded and the ocular fundi visualized. If there is only one functional eye or if there is severe retinal vascular disease, orbital intervention should be avoided. Medical conditions such as hypertension, diabetes, and coagulopathies should be treated and the use of anticoagulants discontinued. The amount of epinephrine in the local anesthetic must be also carefully considered. Patients need to be carefully monitored in the postoperative period. If decreasing visual acuity is found secondary to the suspected orbital hemorrhage, emergency treatment measures should be immediately instituted. These facts must be kept in mind by all surgeons who perform blepharoplasties.

\section{RESUMO}

Blefaroplastia é uma das cirurgias mais comumente realizadas para o rejuvenescimento da região periorbitária. Apresentamos um caso de perda visual unilateral permanente após blefaroplastia de pálpebras inferiores com remoção de gordura. A etiologia da hemorragia retrobulbar após a blefaroplastia, o tratamento e recomendações para reduzir o risco desta rara e séria complicação são discutidos.

Descritores: Cegueira/etiologia; Blefaroplastia/efeitos adversos; Hemorragia retrobulbar/complicações; Cuidados pósoperatórios; Tecido adiposo/cirurgia; Cirurgia plástica/efeitos adversos; Relatos de casos [tipo de publicação]

\section{REFERENCES}

1. DeMere M, Wood T, Austin W. Eye complications with blepharoplasty or other eyelid surgery. A national survery. Plast Reconstr Surg. 1974;53(6): 634-7.

2. Peruzzo M, Mélega JM. Cegueira pós-blefaroplastia estética. Rev Soc Bras Cir Plast. 1988;3(2):138-42.

3. Goldberg RA, Marmor MF, Shorr N, Christenbury JD. Blindness following blepharoplasty: two case reports, and a discussion of management. Ophthalmic Surg. 1990;21(2):85-9.

4. Callahan MA. Prevention of blindness after blepharoplasty. Ophthalmology 1983;90(9):1047-51.

5. Good CD, Cassidy LM, Moseley IF, Sanders MD. Posterior optic nerve infarction after lower lid blepharoplasty. J Neuroophthalmol. 1999;19(3):176-9.

6. Hepler RS, Sugimura GI, Straatsma BR. On the occurrence of blindness in association with blepharoplasty. Plast Reconstr Surg. 1976;57(2):233-5.

7. Hueston JT, Heinze JB. A second case of relief of blindness following blepharoplasty: Case report. Plast Reconstr Surg. 1977;59(3):430-1.

8. Kelly PW, May DR. Central retinal artery occlusion following cosmetic blepharoplasty. Br J Ophthalmol. 1980;64(12):918-22.

9. Mahaffey PJ, Wallace AF. Blindness following cosmetic blepharoplasty - a review. Br J Plast Surg. 1986;39(2):213-21.

10. Putterman AM. Temporary blindness after cosmetic blepharoplasty. Am J Ophthalmol. 1975;80(6):1081-3.

11. Lloyd WC 3rd, Leone CR Jr. Transient bilateral blindness following blepharoplasty. Ophthal Plast Reconstr Surg. 1985;1(1):29-34.

12. Stasior OG. Blindness associated with cosmetic blepharoplasty. Clin Plast Surg. 1981;8(4):793-5.

13. Waller RR. Is blindness a realistic complication in blepharoplasty procedures? Ophthalmology. 1978;85(7 Pt 1):730-5.

14. Heinze JB, Hueston JT. Blindness after blepharoplasty: mechanism and early reversal. Plast Reconstr Surg. 1978;61(3):347-54.

15. Hartley JH Jr, Lester JC, Schatten WE. Acute retrobulbar hemorrhage during elective blepharoplasty. Its pathophysiology and management. Plast Reconstr Surg. 1973;52(1):8-15.

\section{Congresso Internacional da Sociedade Brasileira de Oftalmologia}

20 a 22 de Julho de 2006

Hotel Glória

Rio de Janeiro - RJ

Tel.: (21) 2557-7728

E-mail: sbo@sboportal.org.br 